Miona Miliša

The University of Split

Arts Academy

Conservation - Restoration Department

Croatia
UDC 679.8/.9:7.01

doi: $10.5937 / \mathrm{ZbAkU} 2008234 \mathrm{M}$

Scientific Review

\title{
Pre-Romanesque interlace sculpture: a problem of stone motif terminology
}

\begin{abstract}
Stone sculpture from the period between the beginning of the $8^{\text {th }}$ and the end of the $10^{\text {th }}$ centuries is characteristic for interlace compositions adorning church furniture and architectural elements of the time. In studying Pre-Romanesque stone fragments with interlace motifs and their interpretations in scholarly literature uncoordinated terminology becomes prominent.

From the very beginnings of archaeology and art history in Croatia, in the $19^{\text {th }}$ century terms for motifs carved in stone on Early Medieval interlace reliefs were introduced. In the Eastern Adriatic area motifs have usually been given names by translation of terminology from foreign literature (Italian or German). Different authors use various variants in describing motifs executed in interlace. By taking into account compositions of motifs on Early Medieval interlace reliefs and their interpretation in scholarly literature, inconsistency in the terminology of relief motifs is noted. Nomenclature of motifs, i.e. terminology, is truly important in order for to be able to discuss certain manifestations, but sometimes it could lead the researcher onto the wrong path. Differentiation of terms and objective coordination of different terminology for the same concepts, i.e. equal terminology for different concepts is necessary, always bearing in mind the period in which a certain term is used as well as its true origin.
\end{abstract}

Keywords: Pre-Romanesque stone sculpture, interlace reliefs, motifs, terminology, medieval compositions.

\section{Introduction}

According to most dictionaries, nomenclature is a group of terms or a system of denoting used in a certain branch of science or a technique. In science, such systems were firstly applied in botanics and zoology (Hawkins, 1979: 442-443, 697). Nomenclature is also a list of terms and other signs in a certain profession, its terminology. 
Terms by which we have named certain motifs in order to articulate, group or differentiate them are our own creation. While observing motifs on Early Medieval interlace reliefs and their interpretation in scholarly literature, uncoordinated terminology became prominent. „Reasoning by analogy is the source of countless errors“" (Chevalier, Gheerbrant: 1983: VIII).

The difference in terminology as a result of evolution of Croatian language from the $19^{\text {th }}$ century until today is not the subject of this analysis. The subject is the complete change of terms, i.e. the names of particular motifs. Deviation of the term Vitruvian volute into the term hook might be the best example. Many motifs have experienced terminological renaming by having their names slowly modified through the years.

Nomenclature of motifs, i.e. terminology, is necessary in order to be able to discuss certain manifestations, but sometimes it leads the researcher onto the wrong path. An undistorted perception and an accurate description of visual motifs is a complex procedure. It includes plenty mediators between the stone sculpture itself, the visual fact and their description in words. Differentiation of terms and objective coordination of different terminology for the same concepts, i.e. equal terminology for different concepts is necessary, always bearing in mind the period in which a certain term is used as well as its true origin. Due to language-dependant terminological specificities, this paper is written with Croatian terms /names of motifs, and then their English translation. Where it was necessary German or Italian translation of the term (name of motif) has been given.

Inspiration for this research came to me while reading a book of Frane Bulić from the year of 1888 . The book is first comprehensive work on stone interlace sculpture and motifs on it. Reading that first literature on Croatian language about early medieval interlace sculpture, it is obvious that the authors didn't know about the terms we use today. Due to limited space, all descriptions of some motifs and all the literature which mentions them are not presented in this research. The most characteristic examples of the description of individual motifs are selected.

\section{VITRUVIJEVA VOLUTA (cro.) -VITRUVIUS VOLUTE (eng.)}

Other terms in Croatian:

PASJI SKOK / dog's jump

KUKE / hooks

RAKOVICE / little crabs / „Krabben“" (germ.)

1 Jozef Strzygowski, Die Altslavische Kunst (Augsburg: Filser, 1929), 62. (Krabben - pričajući o oltarnoj pregradi iz Sv. Martina u Splitu) 
Vitruvius was writting about symetrion and proportion. When he talked about „ionic column" he mentioned volutes in the context of the proportion of the column, the thickness of the abacus, etc (Fig. 1.). About the proportions and the method of forming volutes of Ionic capitas Vitruvius says the following: „Axis of volutes should not be thicker than the size of the eye, the volutes should be carved to the twelfth of their height.“(Lopac, Bedenko, 1999: 65-68).

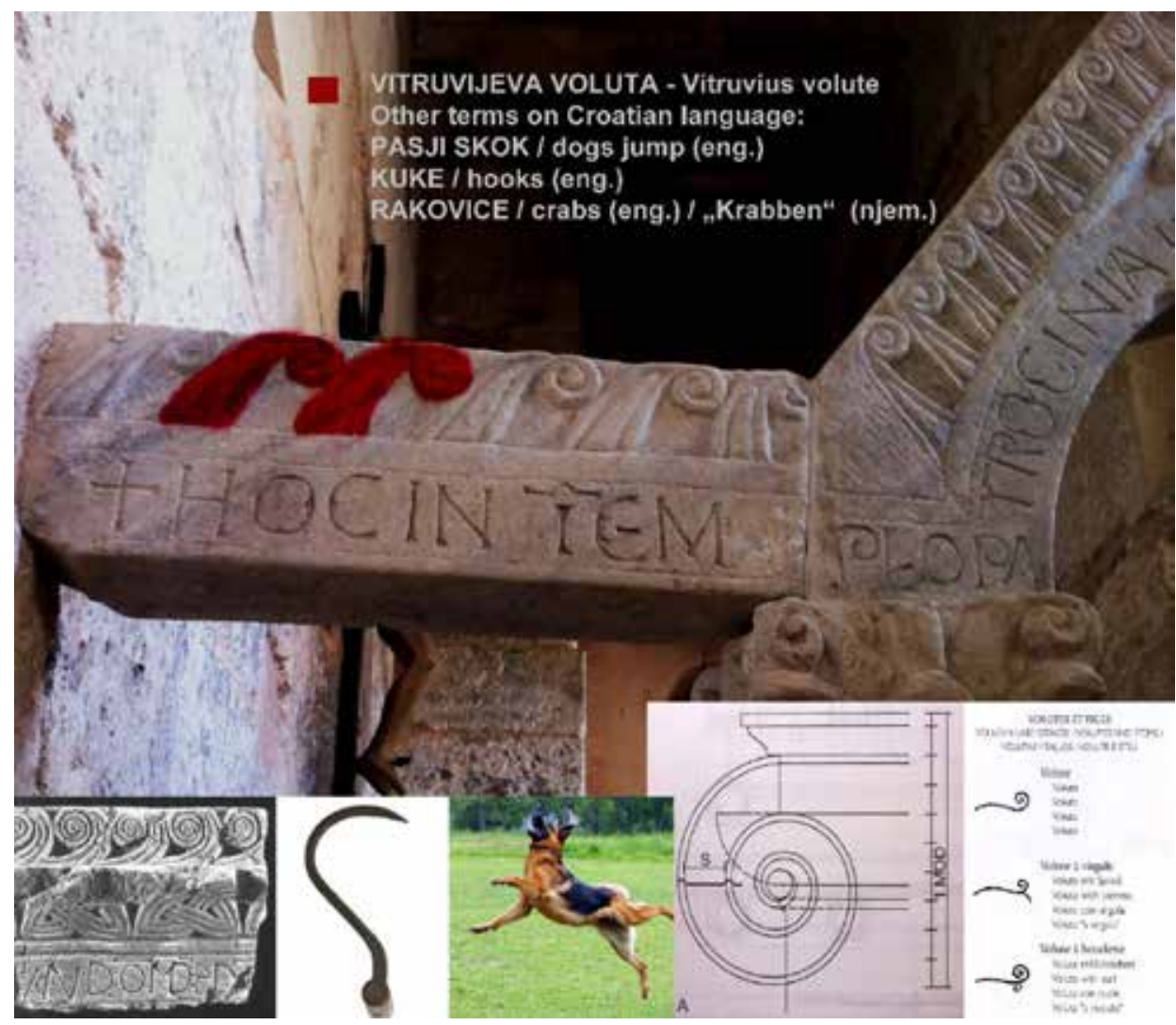

Figure 1. At the beginning of the $20^{\text {th }}$ century motif volute becomes: „Spiralne zavojnice na trotračnim peteljkama" / Spiral coils on threefold petioles (eng.). During the $20^{\text {th }}$ century became: ,pasji skok“ / dog's jump, ,rakovice“ / little crabs and „kuke“ / hooks. Interpretation of different terms for the same motif. ${ }^{2}$ Right Principle of making the volute on ionic capitals. Drawing of Vitruvius volute. (Vitruvius: De architectura libri diecem)

In the year of 1888 Croatian archaeologist F. Bulić used the term volutes (sometimes Vitruvius volutes) while describing stone early Medieval reliefs found in Knin (Bulić, 1888: 43). Today term hooks is used. About 40 years later, in the year of

2 Photo: Miliša, 2013. 
1927, while describing altar screen from St. Martin in Split, Strzygowski used the term little crabs.

„Lower parts of the septum, which are made together with the columns from one piece of stone, wear stone beam; in the middle of the arc the beam is reduced, and ends with the gable. In that gable is little cross with birds, underneath is the inscription, and above all of it we can see a number of crabs which are located above all along the beams and gable. Surface on the lower part have three-rail scroll between the edges“" (Strzygowski, 1927: 20).

Explaining the term „crabs" Strzygowski says: „Crab“ is a spiral decorative element similar to animal species, the so-called little crabs. German term for the same decoration is „Krabben“.

While describing triangular pediment from the church St. Appolinare in Classe from the $9^{\text {th }}$ century, near Ravenna in Italy, Strzygowski says: ,[...] on the edge the crabs are carved“. Later in the text the term „crabs“ is replaced with the term „dog's jump“. „[...] For humanists the question about the origin of this motif is quite simply. For them it is about antique pediment, above which is the motif of dog's jump" (Strzygowski, 1927: 52).

„Rakovica“ / Little crabs is also described like: „Spirals on stalks that are usually standing in rows next to each other we called crabs“" (Strzygowski, 1927: 5758). Stückelberg kept them as original features of Lombard national art, and a harbinger of Gothic crabs. On the contrary, Zimermann thinks that they are nothing else then barbarized antique ornament of dog's jump motif (Strzygowski, 1929: 76-79).

At the beginning of the $20^{\text {th }}$ century ,volute" became: "Spiralne zavojnice na trotračnim peteljkama" / Spiral coils on threefold petioles. And then during the $20^{\text {th }}$ century became: "pasji skok“/ dog's jump (eng.), „rakovice“ / little crabs and „kuke“/ hooks. The motif of hooks can be also find in all parts of the ex-Roman Empire, on the borders of antique mosaics. Balmelle uses the term ,a simple wave pattern“ (Balmelle, 1985: 156).

Generally, in the contemporary literature for the same motif the term "hooks“ is used. For example, here is a description of the architrave of the altar screen from the Monastery of St. Clara in Split. „In the upper field is a row of pitched hooks anderecting left. Legs of the hooks have a groove in the middle, at the bottom part they touch each other as well as the spiral coils at the top" (Piteša, 2012: 67, 94). On the other hand, in the same literature the above mentioned descriptions can be found as following:

„Capitals on the columns are stylized imitation of Corinthian capitals. On the architraves appears certain repertoire of ornaments too. The top edge is carved of rows of 'hooks', which are showing a significantly changed classic motif of 'dog's jump'. The lower part can be treated differently. On the architrave there are often found dedicatory inscriptions in Croatian.“(Jakšić, 1986: 23) 
PEREC MOTIV-PRETZEL MOTIF (eng.), pretzel (germ.), salatino (ital.)

This motif was primarily called endless (infinite) knot. The endless knot, in the classification of types of interlacing was unhappily once called ,pretzel motif“, intertwining infinite, cyclic, three-dimensional and Trinitarian unity. One of the fundamental Pre-Romanesque characters, a simple endless knot, is multiplied in a series or intertwines with different shapes to differentiate the meaning. Its place in the ornamental part or liturgical furniture extends its meaning. Threefold and threedimensional, single or potentiated, (it is three, nine or twenty-seven). It can be traced through the Bible and ancient Christian exegesis, but also in a special way it was expressed in the Pre-Romanesque sculpture (Pejaković, 2007: 539). Simple endless knot tied to the end becomes pentagon and pentagram prophylactic and metric or numerical symbol, associated with the logarithmic spiral, generations, resurrection and baptism. In combination within other forms, its meaning is extended or reduced (Pejaković, 1996: 135-137.). (Fig. 2. b)

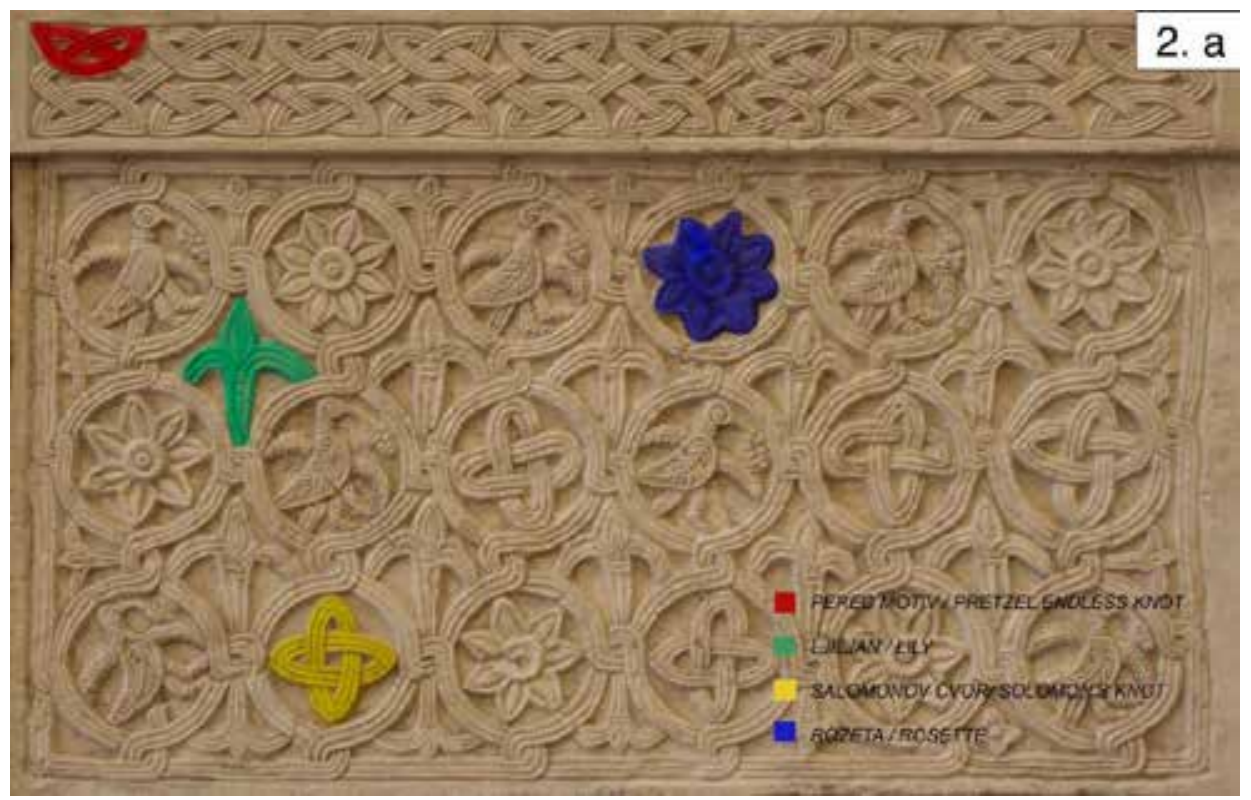

Figure 2.a The motifs mentioned in the text marked on the pluteus from Koljani. The pluteus is exposed in The Museum of Croatian Archeological Monuments, Split. $^{3}$

3 Photo: Miliša, 2014. 


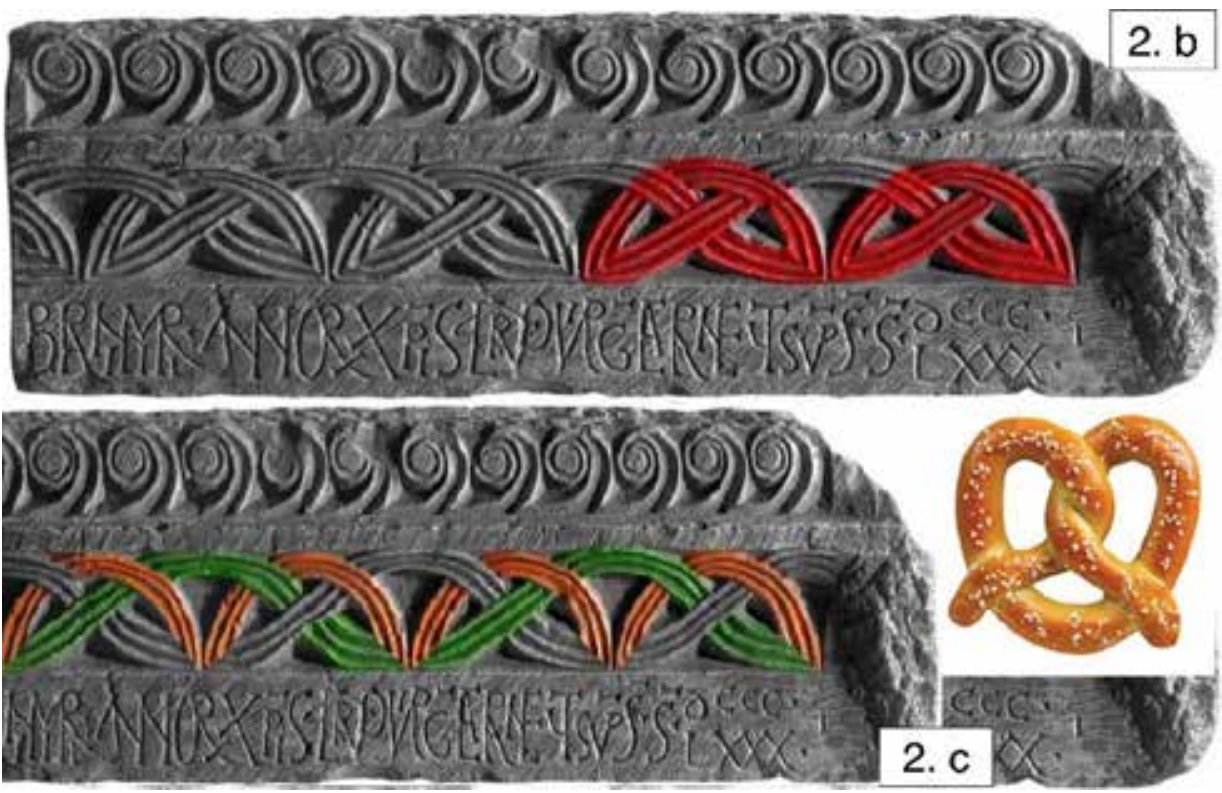

Fig. 2. b Branimir's architrave from Muć. Interpretation of the past 70 years =perec motiv / pretzel motif (eng.). ${ }^{4}$
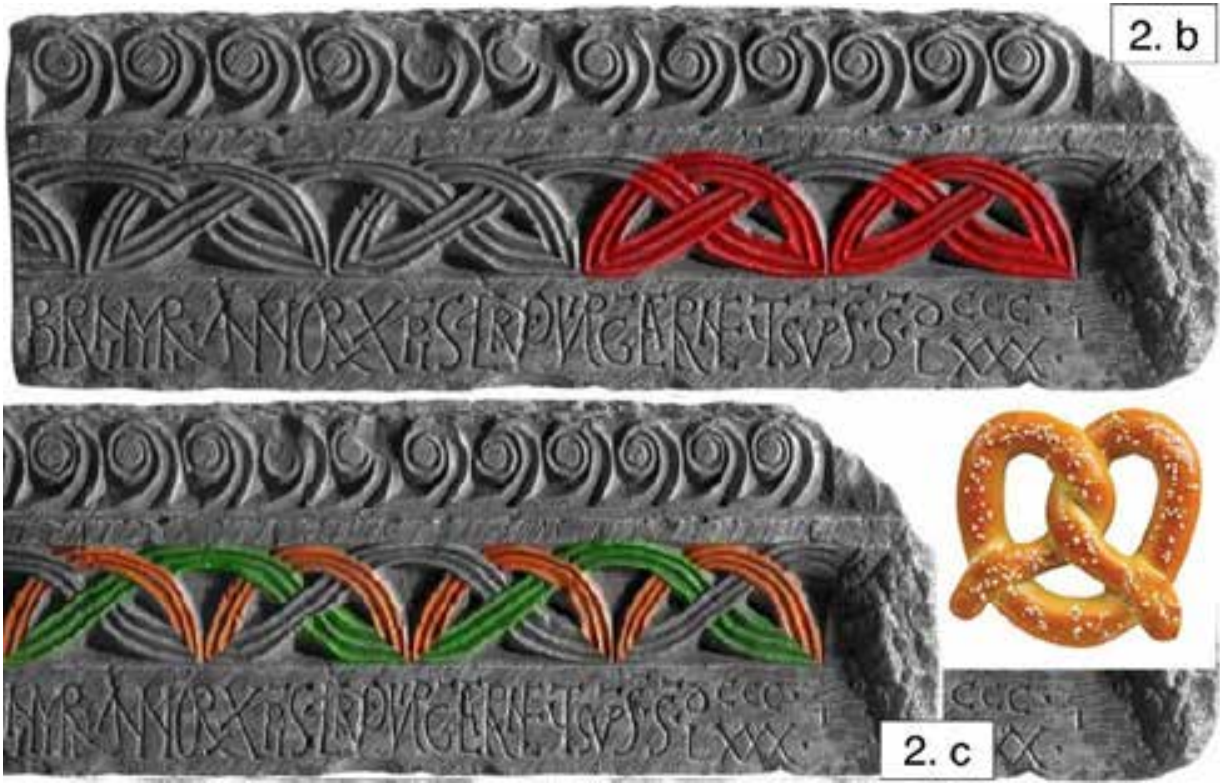

Fig. 2. $\mathbf{c}$ Branimir's architrave from Muć. Interpretation of the early $20^{\text {th }}$ century ${ }^{5}$

4 Photo: Miliša, 2014.

5 Figure from Strzygowski, 1927. 
Describing the fragment with an inscription of Duke Branimir from Muć, from the year of 888, Josef Strzygowski says:

„[...] first we see three-lane ribboned ribbon, and then a row of spirals, which are connected to the three-lane stalks... What did stone mason want to show when he carved in stone those two lines? Interlace shows semicircles to each other, and each two and two connecting third wavy strip. The interlace is much more noticeble than the Latin inscription. It is carefully carved like the crabs above him."(Strzygowski, 1929: 91, fig. 64)

According to the description the pretzel motif is not mentioned. The author describes the motif like semicircles and wavy stripes. (Strzygowski, 1927: 48) (Fig. 2. c)

The continuity of motifs of endless knot (furthermore all its variants [Balmelle, 1989: 349, 414]), three-strand braid into interlacing (Jakšić, 2000: 196; Balmelle et al., 1989: 120), various geometrical compositions, knotted medallions and four lilies in the form of a cross can be traced since ancient mosaic (Jakšić, 2000: 195-197, 201). These are all motifs derived by interlacing, carved in stone directly transferred from the ancient mosaic. For rosette motifs there are direct examples on ancient mosaics (Balmelle et al., 1989: 97), and for a „wavy rose“ there are only analogies which are not the identical motif (Balmelle et al., 2002: 42, 56). (Fig. 2. a, 5.)

SALOMONOV ČVOR-SOLOMON'S KNOT / Salomons knoten (germ.), Nodo di Salomone (ital.)

The motif of Solomon's knot (an interwave of two interlocking ellipsoid forms, one inside the other) is one of the oldest interlace motifs. It is also directly derived from depicting the Antique mosaic floors (Piteša, 2012: 138). Twisted Pretzel motifs are one version of Solomon's knot. (Fig. 2. a, 3.) Sometimes it is called central knot (or alternately reversed) (Balmelle et al., 1989: 107). Solomon's knot could be inscribed within a knotted circle (Balmelle et al., 2002: 88; fig. 3a). Describing a pluteus from the Archaeological Museum in Split, Piteša says: „Between the arch and the frame of the central field a threeribbon Solomon's knot is carved“"(Piteša, 2012: 101-103). (Fig. 3. c)

Figure 3. a) Motiv Salomonovog čvora / Motif of Solomon's knot on antique mosaics. ${ }^{6}$ 3. b) Motif of Solomon's knot on antique mosaics from Split, Supetar and Vid near Metković. $^{7}$

3. c) Solomon's knot is often confused with a so called "pretzel" motif i.e. endless or infinite knot. Pluteus from the cathedral in Split and the Archaeological Museum in Split. ${ }^{8}$

6 Drawings: Balmelle 1985.

7 Photos:Miliša 2013.

8 Drawing: Balmelle 2002, Photos: Miliša, 2014. 

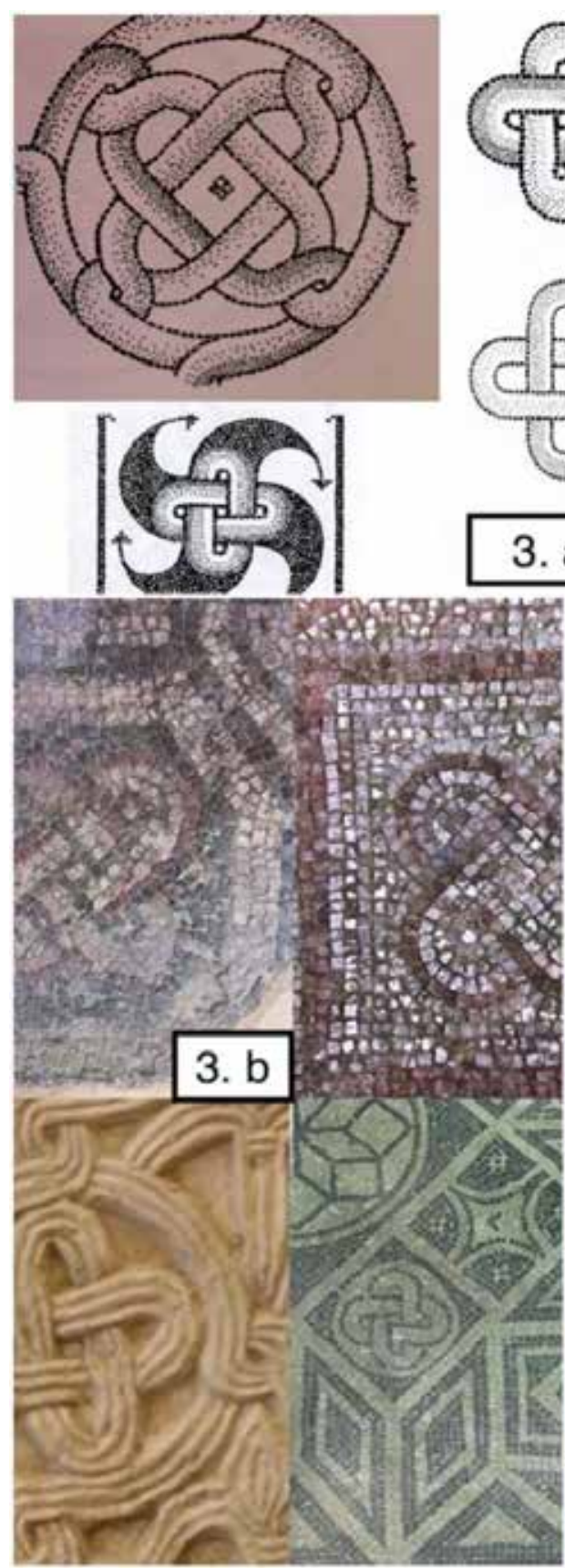

Nœud de Salomon

Flechtbandknoten (Salomonsknoten)

Solomon knot:

Nudo de Salomón

Nodo di Salomone

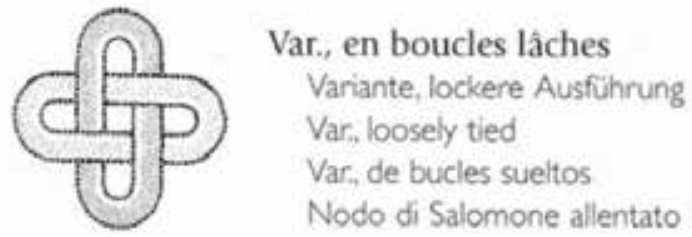

\begin{tabular}{|l|l}
\hline 3. a & Var., autour d'un noeud de \\
Salomon
\end{tabular}

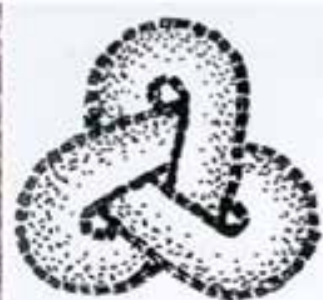

Nound de Knoten Knot of Nudo d Nodo ti

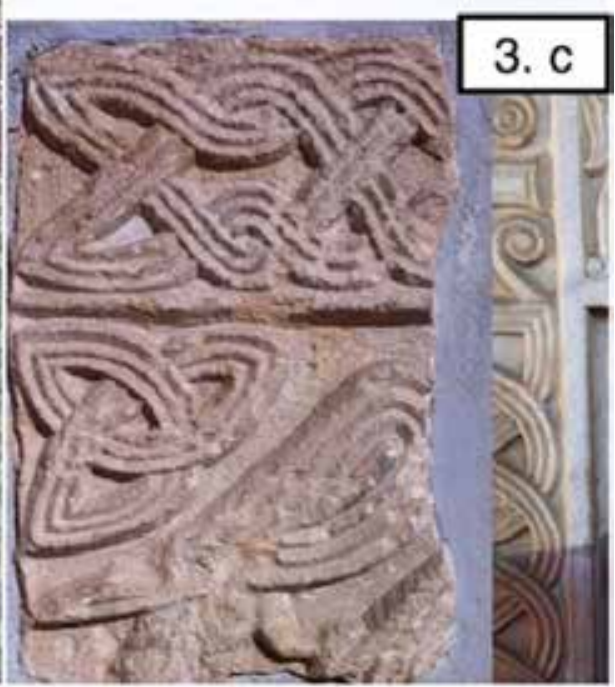


ROZETA-ROSETTE / Rosetten (germ.)

Rosette is defined as a central circular motif. Within this motif there is a flower in different variants. It can appear with rounded petals, pointed petals and with different numbers of petals (Balmelle et al., 2002: 56). The rosette is centralized pattern independent of any external frame and formed primarily of floral elements, which radiate around the point or a central motif, in one or several corollas (Balmelle et al., 2002: 13; Strzygowski, 1929, 25, 96). (Fig. 4. b)

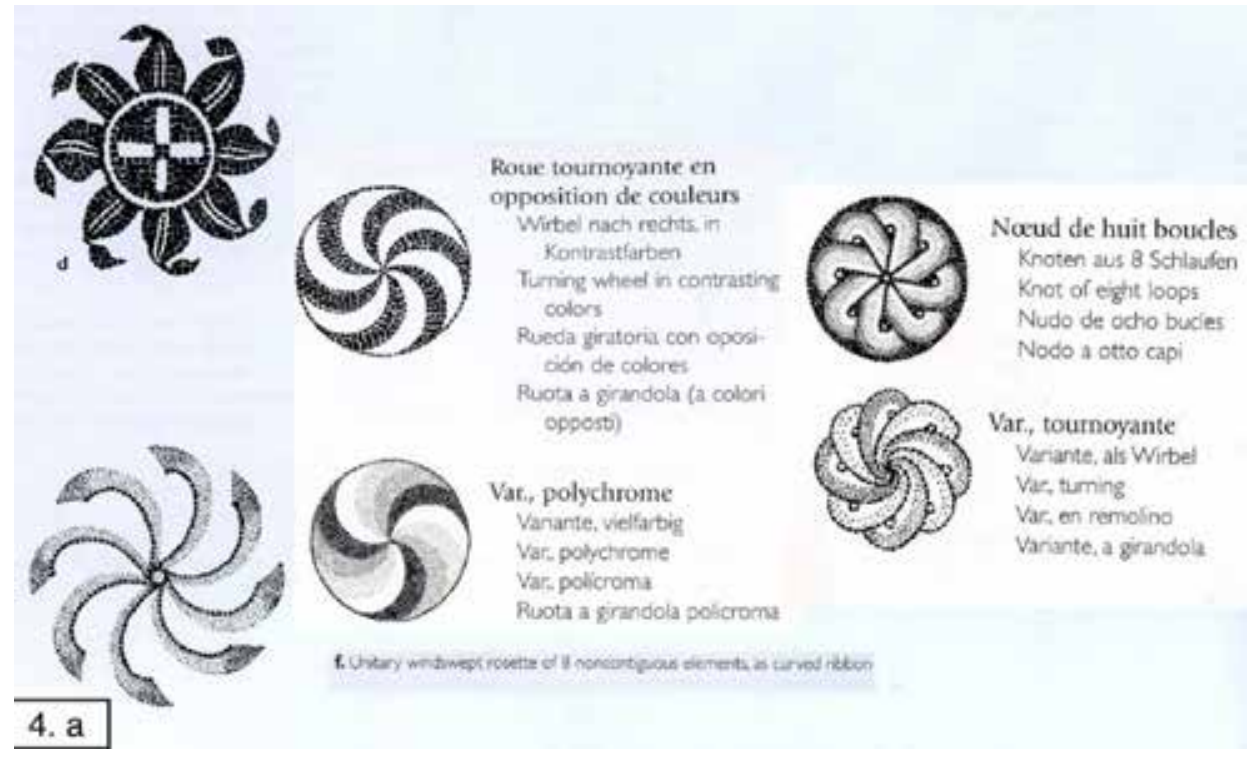

Figure 4. a A rosette is a centralized pattern independent of any external frame and formed principally of floral elements radiating around a point or a central motif, in one or more corollas. ${ }^{9}$ Figure 4. b) One side of the ciborium from the church of St. Chrysogon in Zadar. Interpretation of motifs are marked with different colors. ${ }^{10}$

VIROVITA ROZETA - WINDSWEPT ROSETTE, swirling rosette ${ }^{11}$ or vortex rosette / rosette ondulate, orgirlandola (ital.), wellenförmige Rosetten (germ.) (Balmelle et al., 2002: 56). (Fig.4. a)

9 Drawings: Balmelle, 2002.

10 Photo: Miliša, 2014.

11 Windswept - Balmelle et al., 2002: 56, f; swirling - Piteša, 2012: 142.

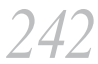


There are several variations of windswept rosetta in ancient mosaics; with the pointed and radial petals (Balmelle et al., 2002: 62). Like unitary windswept rosette (of 8 adjacent elements, as curved triangular trifid petal) It is important to differentiate a motif of rosette, from motif of rose, especially when adjective vortex is added to the descriptions. Rosette is primarily geometric motif, while the rose has a primarily plant connotation. The best examples to understand diversity between „windswept roses“ as the primary plant and „windswept rosettes“ as geometric motifs are from Krk and Omišalj. (Fig. 6. b) Namely, the motif here is conceived in a way that creates a three-strand tress "windswept roses" whose centers are windswept rosettes. Again, it is obvious that the windswept rose is inappropriate term. Much more appropriate term in this case could be radial.

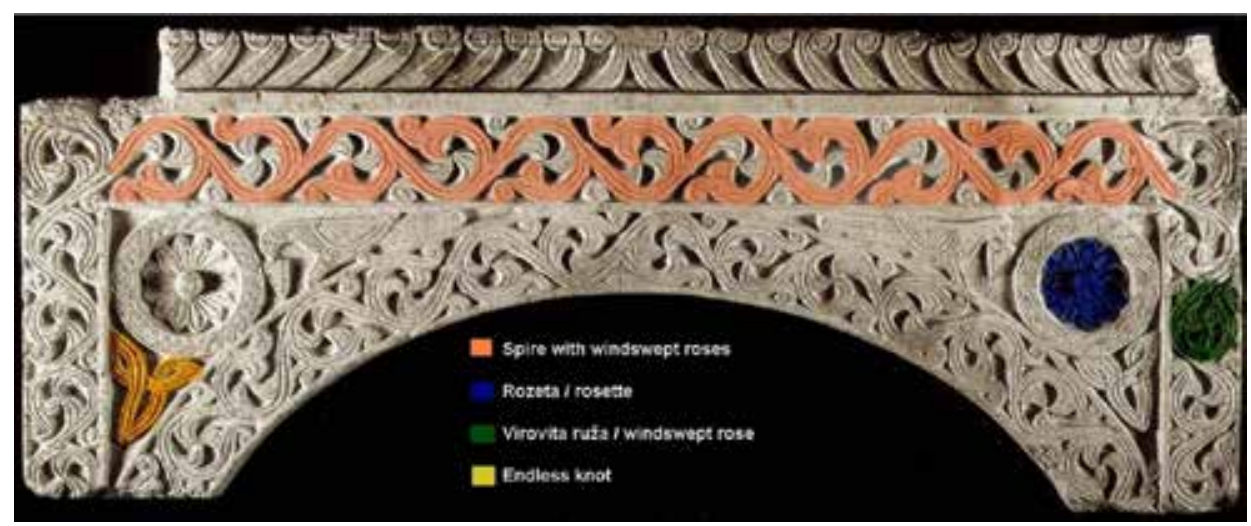

VIROVITA RUŽA-WINDSWEPT ROSE/ wellenförmige Rosen (germ.) (Vogüé and Neufville, 1965: 486)

Among the geometric, vegetable and zoomorphic motifs which appear on the Pre-Romanesque interlace sculpture from Eastern Adriatic coast, within a floral motif the motif of „windswept roses" (or vortical roses) also appears. When windswept rose is described, the combination of terms like rosette, rose, lily, tendrils, wavy and vortical is usually used in literature. In the Glossary the mentioned term is defined as a round, central formations i.e. composition with button in the center around which are the central twisted petals. Seen from the above, all together looks like a rose (Vogüé and Neufville, 1965: 380). (Fig. 5.)

This motif is experiencing a whole range of description and interpretation in the technical and scientific literature during the last hundred years. In the book of Frane Bulić vortical rose is defined as a twelve-petals rose. ${ }^{12}$ In the description of stone fragments from Vrpolje from the first half of the $20^{\text {th }}$ century, written by S. Gunjača, the term ,winch“" is used ${ }^{13}$ (Fig. 5. c). In the documentation about fragments from Rižinice,

12 „Od ornata razabire se obrubni četverostruki gajtan; pak jedan uvojak simboličnog čokota popunjen dvanaest latičnom ružom“ (Bulić, 1898: 44, pl. XVII/56).

13 „Unutar tog rastvorenog koluta nalaze se dočeci od tri latice, koje su izlazile iz jednog centra, širile se 
Vrpolje, Plavno and Biograd, author Nikola Jakšić instead of describing a motif, used term rosettes (Jakšić, 1997: 41-54).

In the following text three different descriptions by three different authors - of the same ciborium from the church of Saint Pelagije from Novigrad in Istra - are given. (Fig. 5. a)

- ,[...] scroll with windswept roses and punched dots...“ (Vežić and Lončar, 2009: 260). - „Floral geometrical scroll which closes circles with windswept roses and circles are joined with caracteristic plate with three holes" (Jurković, 2000: 53).

- , [...] decorated with a row of flowered rosettes which consist of sickle rays“ (Jakšić, 1991: 22). According to the descriptions without photos, it is difficult to conclude that this is the same decoration.

Furhermore, different descriptions of the same author can be found in two different articles. He described the pluteus and pilaster of the altar screen in Valbandon near Fažana:

- , $[\ldots]$ on the cornice there is a classic row of Pre-Romanesque rosettes in an intermittent tendril" (Jakšić, 2000: 74).

- ,The upper beam is carved with a decorative field and decorated with ten three-lane circles with rosettes“ (Jakšić,1991: 22).

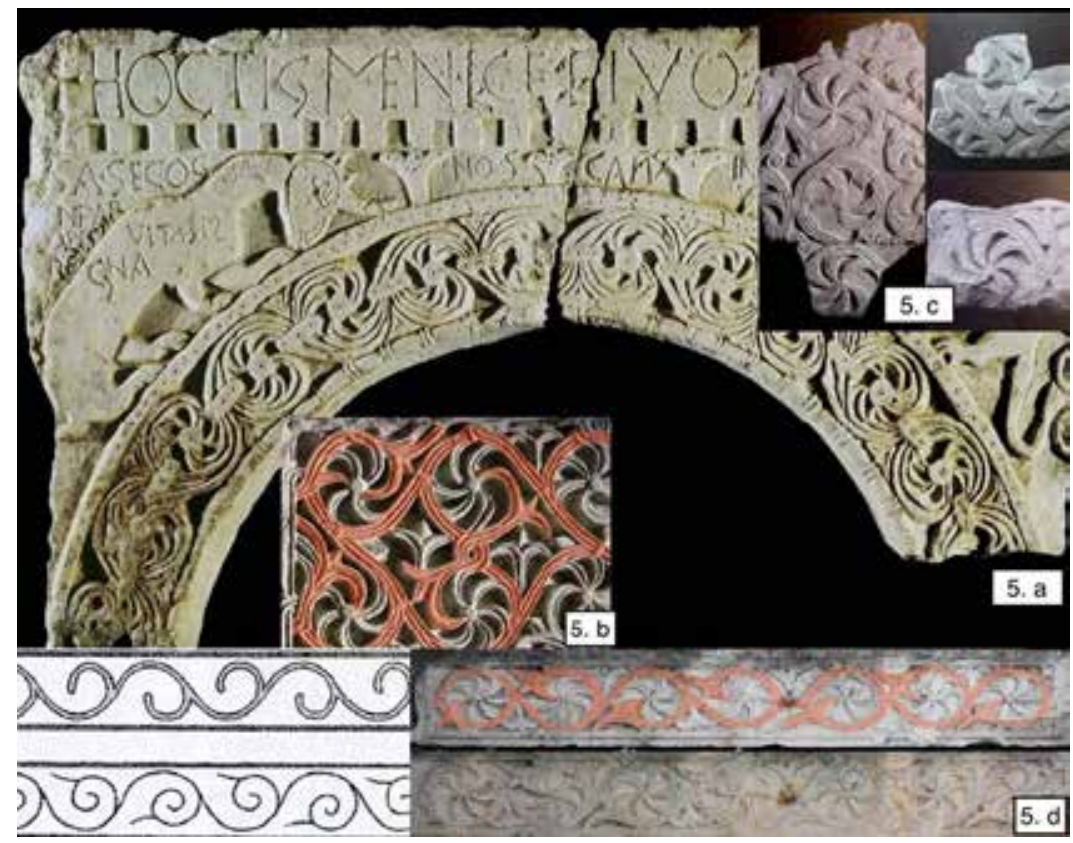

Figure 5. a Arcade of the ciborium of Bishop Mauritius from St. Pelagius in Novigrad Istria, near the $8^{\text {th }}$ or early $9^{\text {th }}$ century. ${ }^{14}$

i savijale prema kružnici u vidu kašika vitla." (Gunjača, 2009: 29-31) 14 Vežić, 2009. 
5. bVirovita ruža /vortex , windswept or swirling rosette (eng.). Right field of pluteus, today located in the north wall of the church of St. Nicholas in Dubrovnik. ${ }^{15}$

5. c Vitlo / winch (eng.) In the first half of the $20^{\text {th }}$ century this motif was even called a winch. ${ }^{16} \mathbf{5}$. $\mathbf{d}$ We look at the tendril of the same plant or the same plant motif, whose ends become buds of lilies. This is an interesting example of how the "windswept rose“ is actually blooming lily seen from the above. Pilaster from Dubrovnik. Drawings of Voluted stylized scroll. ${ }^{17}$

While describing a fragment of pluteus from Muć Gornji, the author has not used the term „windswept rose“ (Piteša, 2012: kat. br. 150). He describes the motif in detail: ,a three-lane circle with three separate, rounded triple ribbons, suggesting a swirling motion"(Piteša, 2012: 84-86), which seems to be a better solution. Descriptions of the ciborium from St. Grisogono in Zadar (Fig. 4.b):

„The ornament is formed by vine scroll, which extends in the form of a wavy line along the arcade. The stalk of vine scroll is three-laned. There is a pattern in branching of short withes, curved in a circular shape with a volute at the end, from it. From withes in circles of stems, curling leaves resemble windswept rosettes. In the triangular fields, there is located one large rosette with a bird and three-cornered pretzel at the bottom. The rosette is composed of concentric circles ... and in it a blooming flower with twelve petals:" (Vežić and Lončar, 2009: 87, 278).

- „The composition is structured in a way that a continuous series of windswept rosettes goes around the entire surface of the arcades, and in the angles there dominate the plastic rosettes with prominent button in them"(Jakšić, 2000: 166; Jakšić, 1991: 25).

The monolithic pillar from Dubrovnik has one of the four sides decorated with vertical row of ,swirling roses“. „The decoration is made of vertical row of windswept rosettes, which are surrounded by triple strips, which are transformed into knots on the intersection with a rosette. From each opposite knot there comes a lily. With its inner petal the lily touches the ball of windswept rosettes. Spaces between the rosettes and three-ribbon lanes are filled with a lily motif" (Žile,1996: 279-295) (Fig. 5. d). One side of a ciborium, also from Dubrovnik is characterized by floral ornament with three-lane stalk which is all inside the triangular zones of arcade (Menalo, 2003: 52-53). Pekovic considered that it is one of the narrow sides of the smaller ciborium (Peković, 2010: 157). Braided tendrils bend in the $S$ lines, ending with a lily motif. In the upper right and left corner it turns into a „windswept rose“ (Fig. 6. c). Since it is the tendril of the same plant or the same floral motif, whose ends become buds of lilies, this could be an interesting example of how the „windswept rose“ is actually blooming lily seen from

15 Photo: Miliša, 2014.

16 Gunjača, 2009.

17 Photo: Miliša, 2012, Drawing: Balmelle, 1985. 
above. ${ }^{18}$ (Fig. 5) Jurkovic wrote about these fragments attributing them to others in the Dubrovnik area, placing them in the second half of the $10^{\text {th }}$ and the first half of the $11^{\text {th }}$ century (Jurković, 1985: 195).

\section{LJILJAN - LILY and Motiv kosog križa od ljiljana / lily cross motif}

The lily motif appears on Pre-Romanesque sculptures in several variants. It can be independent as an end of an interlace spire, but also in the composition of the four flowers which are diagonally set, whose lateral petals form heart-shaped empty surfaces. Due to ambiguity in historical descritpions, the lily cross motif could also be defined by someone as a clover motif. (Fig. 6. b)

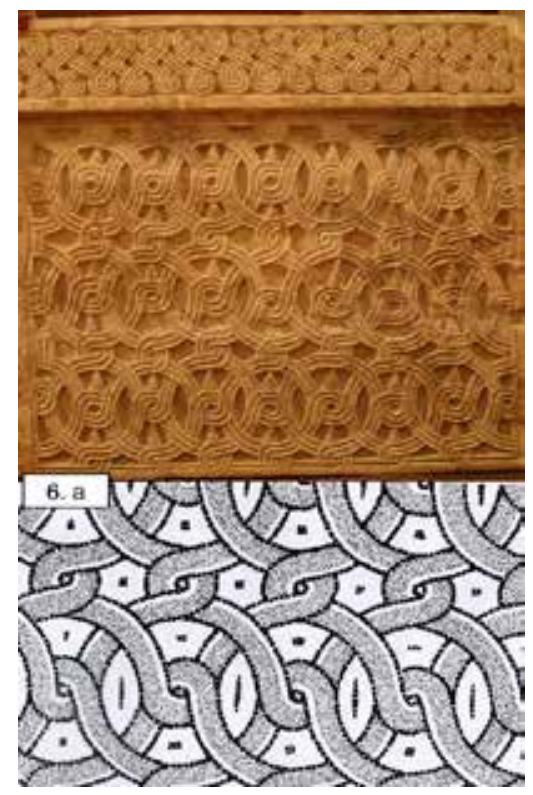

Figure 6 a. Interlaced motifs and compositions, also directly derived from Antiquity. The pattern of rows of tangent and intersecting circles, in interlaced and tangentially interlooped bands. Pluteus is exposed at the Archeological Museum in Dubrovnik. ${ }^{19}$

Figure 6. b Motiv kosog križa od ljiljana / lily cross motif (eng.) A lily cross motif also could be a "clover motif" if first noticed as such. Pluteus is exposed at the Archeological Museum in Split. ${ }^{20}$

18 More about this subject in - Miliša, 2014.

19 Photo: Miliša, 2012, Drawing: Balmelle, 1985.

20 Photo: Miliša, 2014.

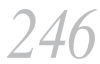




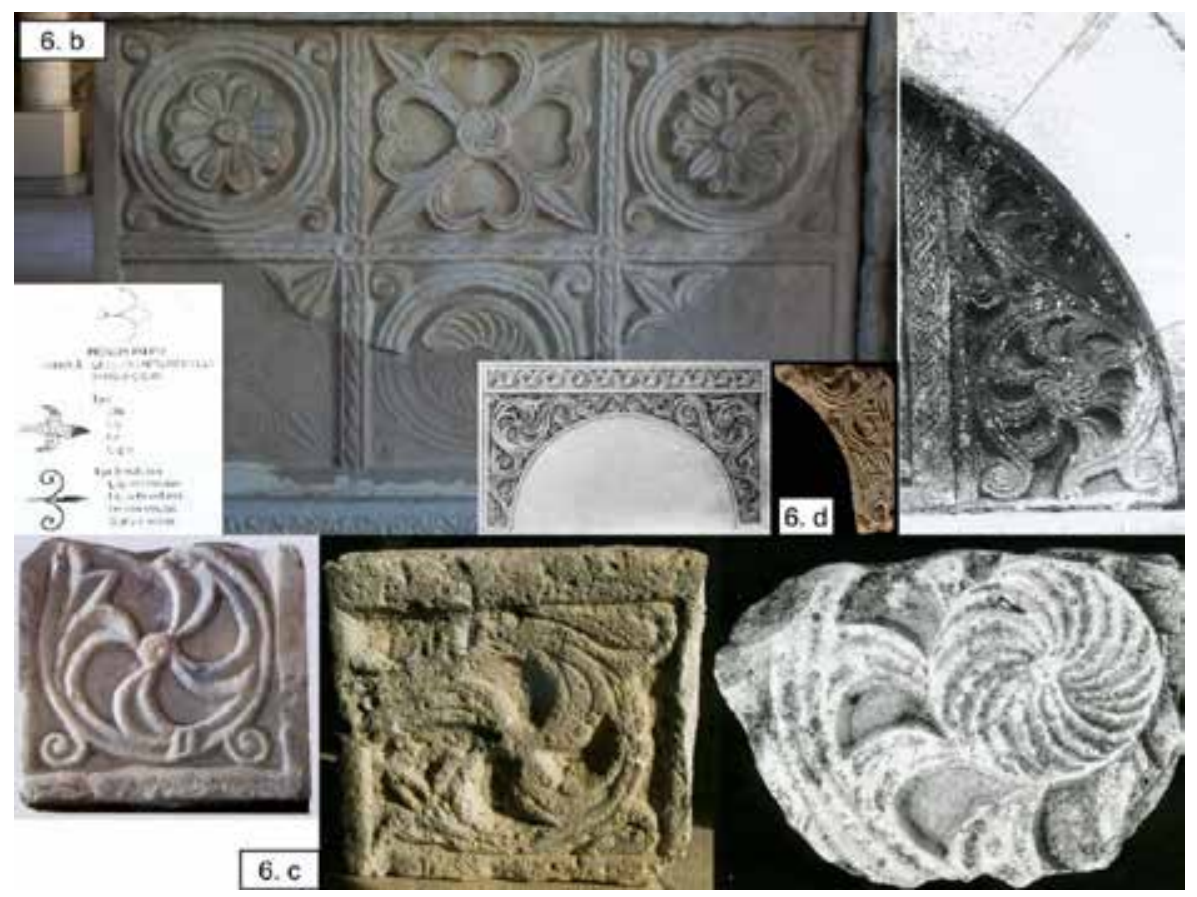

6. $\mathrm{c}$ These are the best examples for distinguishing a windswept rosette from a windswept rose. Stone reliefs are from Omišalj, Krk and Rab. ${ }^{21}$

6. $\mathbf{d}$ This is the best example of how the lily motif becomes a windswept rose. ${ }^{22}$

In the article about the so-called sarcophagus of John of Ravenna, Lj. Karaman wrote: „Diagonally crosses are combined of four lilies i.e. stylized three-lobed leaves“ (Karaman, 1924-1925: 50). It looks like he was not satisfied with the term lily cross, although that term is highly accepted among others authors. ${ }^{23}$ Z. Gunjača reaffirms Karaman's thesis that the lily cross motif belongs to the Early Medieval Croatian interlaced decorations (Gunjača, 1992: 194-196). A detailed analysis of lily-crossed motiłfs can be seen in the article of Basić and Jurković (Basić, 2006: 75-110; Basić and Jurković, 2011: 153-167).

\section{Motiv LIRICE / motif of lyre}

Original Pre-Romanesque doorjambs of the main portal of St. Peter in Dubrovnik are in secondary use (window frames for communion). They are situated on the west wall of the concert hall of the Luka Sorkočević Music School in Dubrovnik.

21 Skoblar, 2006.

22 Drawing: Bakulić, 1999.

23 More about the origin and analogies of lily motifs: Piteša, 2012: 141. More about a lily cross motif: Piteša, 2012: 143. 
Some elements of the doorjambs are decorated with this motif. (Fig. 7. c) The so-called lyre motif author I. Žile described as a mirrored S spirals: „The decoration is made of the mirrored S spiral system, carried out in two horizontal lines. Spirals ends with a pellet, while the inside of spirals is decorated with palmettos..." (Žile, 1996: 280). On the Pluteus from Koločep both motifs of vertical and horizontal rows of heart-shaped ornaments are depicted. The motif can also be found among the range of motifs with mosaic composition: „The row of quasi-tangent alternately reversed S-es (forming tangent involuted hearts alternately inverted) linked to the upper and lower curves (Balmelle et al., 1989: 143, a-b). (Fig. 7. b-c) Or when they are in a vertical row: „A band of superposed involuted linear hearts, forming a wave-pattern" (Balmelle et al., 1989: 148, c).

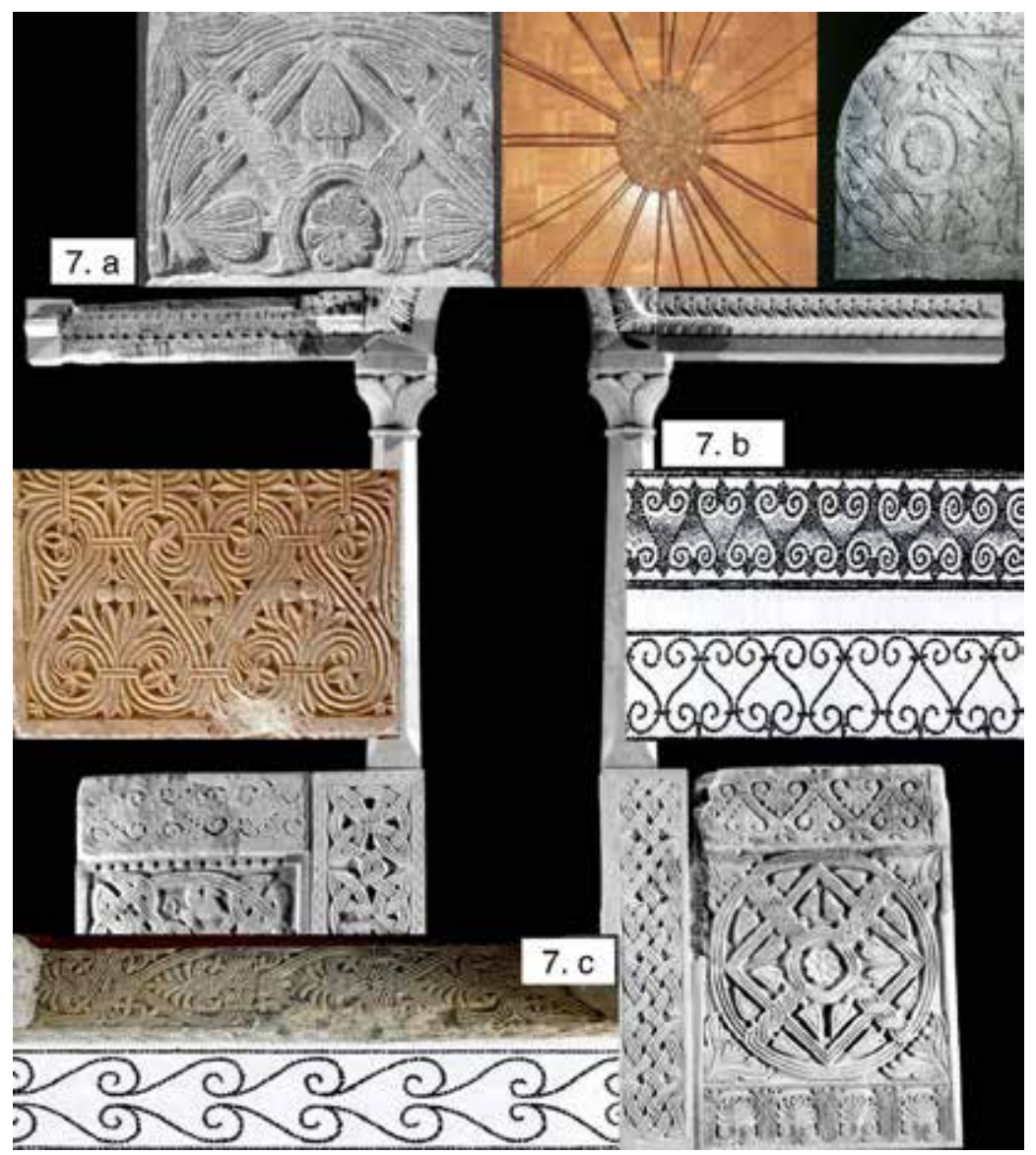

Figures 7. a Motiv dna košare / motif of the bottom of a basket (eng.) Pluteus from Božava and Trogir. 
7. b Row of quasi-tangent alternately reversed S-es (forming tangent involuted hearts alternately inverted) linked to the upper and lower curves. Altar screen from Koločep. ${ }^{24}$ 7. c Motiv lirice / lyre (eng.) Band of superposed involuted linear hearts, forming a wave - pattern..$^{25}$

GLOSSARY (Balmelle et al., 2002: 25.26)

Corolla: in rosettes, refers to each circle of elements arranged around the center. Rosettes are said to have two or more corollas when their elements appear in more than one row; beyond the second corolla, the elements are never attached to the center.

Interlaced: (sculpture): said of two figures or two linear structures formed of bands that pass loosely over and under each other.

Interlooped: said of two figures or two linear structures formed of bands that pass tightly over and under each other.

Motif: is a simple or complex geometric figure essential to any geometric pattern. A simple motif is defined by a single line, continous or broken, usually closed, and of a recognizable shape. A complex motif is any autonomus figure made from an ornamented simple motif or by grouping simple motifs.

Rosette: centralized pattern independent of any external frame and formed principally of floral elements radiating around a point or a central motif, in one or more corollas. The central motif is necessairly smaller than the surrounding elements. The constituent elements of the first corolla are usually contiguous to the center, unless it is indicated that they are „unattached to the center". The center of the rosette is most often circular; it is called a „large circle" when its diameter is equal to or greater than half the radius of the rosette; the center is said to be overlapping if it encroaches on the lower part of the elements in the first corolla.

Windswept: said of a rosette all of whose constituent elements curve in the same direction.

Among all the above mentioned descriptions of different motifs on the PreRomanesque sculpture, one of the most reputable examples regarding terminology is the book about motifs and motives on ancient mosaics written by Blamelle. Inside the book the drawings are classified in a manner that pays no heed to historical or stylistic considerations and has no chronological significance. The descriptions are purely geometric, even if they tend, to the degree that is possible, towards a standardized terminology. They do not include the interpretations one can give to particular patterns (for example, as projections of vaults, ceilings or domes). It must be emphasized that this classification is arbitrary; its sole criteria are an ordering and grouping by means of

24 Photo: Miliša, 2012, Drawing: Balmelle, 1985.

25 Photo: Miliša, 2012, Drawing: Balmelle, 1985. 
formal analysis (Balmelle et al., 2002: 13). The most typical motif carved in interlace sculpture, could also be found in mosaic compositions. „Pattern of rows of tangent and intersecting circles, in interlaced and tangentialy interloope bands" (Balmelle et al., 1989:368). (Fig. 6. a)

Beside inadequate terminology, variations in descriptions could lead to wrong conclusions, or develop thoughts in another direction. The terminology is necessary, but it must never stop researching thought and must not be purpose to itself. The terms which are used to describe stone reliefs or motifs or ornamental compositions on them are useful for organization and clasification of data. They did not exist in the moment when stone sculpture was created. Mostly the terms of motifs were modified through the history by different authors. Deviations in the terminology occurred with the motifs on some other art objects, too. For example, for some parts of the sword: nakrsnica / cross guard - Križnica - križ / cross, or parts of liturgical furniture: oltarna pregrada /altar screen - predoltarna ograda / altar barier-cancellum, etc.

\section{Conclusion}

It was difficult to translate this article into another language, because the specific terminology refers to the terms in the Croatian literature. Furthermore, a very important part of the research is related to the analogy of individual motifs and for the same motifs a term in a foreign language is used. Different terminology and descriptions by different authors occurred through time and its prisms. In order to discuss PreRomanesque sculpture and its motifs in a richer language, it is necessary to systematize basic terminology. This research should be the first step in an effort of coming closer to the solution of the problem, since in the correct interpretations of motifs and the systematization of terminology lie the answers and solutions of many confusions.

While observing and then describing a motif we must always bear in mind the aspect of the original polychromy. All Pre-Romanesque sculptures were colored, but traces of the original color have been preserved on a few artifacts only. We must not forget that the finishing layer of polychromy on Pre-Romanesque reliefs surely sometimes suggested motif differentiation. What present-day research can give is a range of chemical pigment analyses interpreted in an interdisciplinary collaboration of different activities (Miliša, 2014: 174-200). Giving importance to remains of the original polychromy (not just the visible ones, but also some secondary details) on ancient stone, the main motif can be discerned with certainty from the secondary one and thus provide us with a step forward in understanding of motifs, their mutual relations and meanings. 


\section{REFERENCES:}

1. Balmelle, Catherine, and Michèle Blanchard-Lemée, and Jeannine Christophe, and Jean-Pierre Darmon, and Anne-Marie Gumier-Sorbets, and Henri Lavagne, and Richard Prudhomme, and Henri Stern. Le décor géométrique de la mosaïque Romaine I: Répertoire graphique et descriptif des compositions linéares et isotropes. Paris: Picard, 1985.

2. Balmelle, Catherine, and Michèle Blanchard-Lemée, and Jean-Pierre Darmon, and Suzanne Gozlan, and Marie-Pat Raynaud. Le décor géométrique de la mosaïque Romaine II: Répertoire graphique et descriptif des décors centrés. Paris: Picard, 2002.

3. Basić, Ivan, „Skulptura s motivom ukriženih ljiljana na istočnom Jadranu“ [Sculpture with lilycross motif on the eastern Adriatic] Radovi studenata Odsjeka za povijest umjetnosti 4 (2006): 75-110.

4. Basić, Ivan and Miljenko Jurković. „Prilog opusu Splitske klesarske radionice kasnog VIII. stoljeća." [Contribution to the opus of the late $8^{\text {th }}$ century masonry workshop from Split] Starohrvatska prosvjeta 38 (2011): 149-185.

5. Bulić, Fran: Hrvatski spomenici u kninskoj okolici, uz ostale suvremene dalmatinske, iz dobe narodne hrvatske dinastije, sv. I, [Croatian monuments in Knin aerea, along with other contemporary Dalmatian, from the period of the Croatian national dynasty], Zagreb: Jugoslavenska akademija znanosti i umjetnosti, 1888.

6. Chevalier, Jean and Alain Gheerbrant. Rječnik simbola: mitovi, sni, običaji, geste, oblici, likovi, boje, brojevi. [Dictionary of Symbols: myths, dreams, customs, gestures, shapes, characters, colors, numbers] Zagreb: Nakladni zavod Matice hrvatske, 1983.

7. De Vogüé, Melchior, and Jean Neufville. Glossaire de termes techniques à l'usage des lecteurs de "la nuit des temps". Zodiaque, 1965.

8. Gunjača, Stjepan. Tiniensia Archaeologica Historica Topografica. Split: Muzej hrvatskih arheoloških spomenika, 2009.

9. Gunjača, Zlatko. „O podrijetlu motiva križa od ljiljana.“ [On the origins of a lily cross motif] In: Prijateljev zbornik I. Prilozi povijesti umjetnosti u Dalmaciji 32, edited by Joško Belamarić, 193-207. Split: Regionalni zavod za zaštitu spomenika kulture u Splitu 1992.

10. Hawkins, Joyce, M., comp. The Oxford Dictionary of Modern English. Oxford: Oxford University Press, 1979.

11. Jakšić, Nikola. Kiparsko klesarske radionice u Dalmaciji od 9. do 12. stoljeća. [Sculptors stonemasonry workshops in Dalmatia from the 9th to the 12th century] PhD diss., Sveučilište u Zadru, 1986.

12. Jakšić, Nikola. „Predromaničko kiparstvo.“ [Pre-Romanesque sculptures] In: Tisuću godina hrvatske skulpture, edited by Igor Fisković, 13-26. Zagreb: Muzejsko-galerijski centar, 1991.

13. Jakšić, Nikola. „Croatian art in the second half of the ninth century."Hortus artium medievalium 3 (1997): 41-54.

14. Jakšić, Nikola. „Klesarstvo u službi evangelizacije.“ [Stone masonry in the service of evangelization] In: Hrvati i Karolinzi I. Rasprave i vrela, edited by Ante Milošević, 192-213. Split: Muzej hrvatskih arheoloških spomenika, 2000.

15. Jakšić, Nikola. „Valbandon kod Fažane, Vela Boška.“ [Valbandon near Fažana, Vela Boška] In: Hrvati i Karolinzi II. Katalog, edited by Ante Milošević, 73-74. Split: Muzej hrvatskih arheoloških spomenika, 2000.

16. Jurković, Miljenko. „Prilog određivanju južnodalmatinske grupe predromaničke skulpture.“ [Contribution to the determining South Dalmatian group of Pre-Romanesque sculpture] Starohrvatska prosvjeta 15 (1985): 183-199. 
17. Jurković, Miljenko. „Arhitektura karolinškog doba.“ [Architecture of the Carolingian period] In: Hrvati i Karolinzi I. Rasprave i vrela, edited by Ante Milošević, 162-189. Split: Muzej hrvatskih arheoloških spomenika, 2000.

18. Karaman, Ljubo. „Sarkofag Ivana Ravenjanina u Splitu i ranosrednjovjekovna pleterna ornamentika u Dalmaciji." [Sarcophagus of John of Ravenna in Split and early medieval interlaced ornaments in Dalmatia] Starinar 3 (1924-1925): 43-59.

19. Menalo, Romana. Ranosrednjovjekovna skulptura. / Early medieval sculpture. Dubrovnik: Arheološki muzej, Dubrovački muzeji, 2003.

20. Miliša, Miona. „Interpretacije predromaničke pleterne skulpture iz aspekta polikromije i postupka izrade samih kamenih reljefa." [Interpretation of the Pre-Romanesque interlace sculpture from the aspect of polychromy and the construction method of the stone relief] Zbornik radova s prve medievističke znanstvene radionice u Rijeci, (2014): 173-206.

21. Miliša, Miona. „Motiv virovite ruže na predromaničkom liturgijskom namještaju.“ [Motif of windswept rose on Pre-Romanesque liturgical furniture] Hrvatski povjesničari umjetnosti: Radovan Ivančević (1931.- 2004.), (2014): submitted for printing in August 2014.

22. Pejaković, Mladen. „Znakovi i značenja u hrvatskoj predromanici.“ [Sings and Meanings in Croatian Pre-Romanesque] In: Hrvatska i Europa. Kultura, znanost i umjetnost I, Srednji vijek (VII. - XII. stoljeće) Rano doba hrvatske kulture, edited by Ivan Supičić, Zagreb: HAZU - AGM, 2007.

23. Pejaković, Mladen, Omjeri i znakovi: ogledi iz starije hrvatske umjetnosti [Ratios and signs: overviews of the older Croatians art], Dubrovnik: Matica hrvatska, 1996.

24. Peković, Željko. Crkva Sv. Petra Velikoga, Dubrovačka predromanička katedrala i njezina skulptura / La chiesa di S. Pietro Maggiore, La cattedrale preromanica di Ragusa e il suo arredo scultoreo. Dubrovnik - Split: Omega Engineering - Centar Studia mediterranea, 2010.

25. Piteša, Ante. Ranosrednjovjekovni kameni spomenici u Arheološkom muzeju u Splitu. / Early medieval stone monuments in the Archaeological Museum in Split. Split: Arheološki muzej u Splitu, 2012.

26. Strzygowski, Jozef. O razvitku starohrvatske umjetnosti. Prilog otkriću sjeverno-evropske umjetnosti. [About the development of early Croatian art. Contribution to the discovery of northEuropean art] Zagreb: Matica hrvatska, 1927.

27. Strzygowski, Jozef. Die altslavische Kunst. Augsburg: Filser, 1929.

28. Vežić, Pavuša and Milenko Lončar. Hoc Tigmen: ciboriji ranoga srednjeg vijeka na tlu Istre $i$ Dalmacije. [Hoc Tigmen: Ciboriums from the early Medieval period on the territory of Istria and Dalmatia] Zadar: Sveučilište u Zadru, 2009.

29. Vitruvius Pollio, Marcus. De architectura libri diecem / Deset knjiga o arhitekturi. Translated by Matija Lopac and Vladimir Bedenko, Zagreb: Golden marketing - Tehnička knjiga, 1999.

30. Žile, Ivica. „Novi nalazi predromaničke plastike u dubrovačkom kraju.” [New findings of PreRomanesque sculpture in Dubrovnik area] In: Starohrvatska spomenička baština: rađanje prvog hrvatskog kulturnog pejzaža, edited by Miljenko Jurković and Tugomir Lukšić, 279-295, Zagreb: MGC - Odsjek za povijest umjetnosti Filozofskog fakulteta Sveučilišta u Zagrebu Nakladni zavod Matice hrvatske, 1996. 


\section{Predromanička pleterna skulptura: problem terminologije motiva u kamenu}

Apstrakt: Kamena skulptura iz perioda između početka 8. i kraja 10. veka karakteristična je po pleternim kompozicijama koje ukrašavaju crkveni nameštaj i arhitektonske elemente toga vremena. Proučavajući predromaničke kamene fragmente s pleternim motivima i njihove interpretacije $u$ literaturi, dolazi do izražaja neusklađena terminologija.

Od samih početaka razvoja arheologije i istorije umetnosti u Hrvatskoj, još u 19. veku su uvedeni nazivi za motive isklesane $u$ kamenu na pleternim reljefima ranog Srednjeg veka. Na području istočnog Jadrana, motivi su obično dobijali imena prevođenjem terminologije iz strane literature (italijanske ili nemačke). Različiti autori koriste se različitim varijantama opisujući motive izvedene u pleteru. Uzimajući u obzir kompozicije motiva na nekim pleternim reljefima ranog Srednjeg veka, kao i njihove interpretacije u literaturi, uočava se nedoslednost $u$ terminologiji motiva na reljefima. Nomenklatura motiva, odnosno terminologija je zaista važna kako bi se moglo razgovarati o određenim pojavama, ali ona ponekad navodi istraživača na pogrešan trag. Neophodna je diferencijacija termina i objektivno usaglašavanje različite terminologije za iste pojmove, odnosno jednake terminologije za različite pojmove, uvek imajući u vidu razdoblje u kojem se određeni pojam koristi, kao i njegovo izvorno poreklo.

Ključne reči: predromanička kamena skulptura, pleterni reljefi, motivi, terminologija, srednjovekovne kompozicije. 